\title{
SPEECH ACTS DIRECTIVE AND STRATEGY INDONESIAN LANGUAGE TEACHERS IN LEARNING IN CLASS VII OF SMP NEGERI 2 KINALI
}

\author{
Yulina Wisna Jaya ${ }^{1}$, Ngusman Abdul Manaf ${ }^{2}$, Novia Juita ${ }^{3}$ \\ ${ }^{1}$ Postgraduate Program of Indonesian Language And Literature Education, Universitas \\ Negeri Padang \\ ${ }^{2}$ Postgraduate Lecturer of Indonesian Language And Literature Education Universitas \\ Negeri Padang \\ ${ }^{3}$ Postgraduate Lecturer of Indonesian Language And Literature Education Universitas \\ Negeri Padang \\ Email: yulina@gmail.com
}

*Corresponding Author, Received: November 12, 2019, Revised: December 10, 2019, Accepted: December 21, 2019

\begin{abstract}
This research is backed by the problem of frequent misunderstandings between students and teachers. The misunderstanding occurs because students are less able to understand the intent and purpose that the teacher delivered. The purpose and objectives of the teacher cannot be well received by the students because of the form and strategy used by the teacher less according to the situation and condition when said. This research was conducted to explain the follow-up and strategy to speak Indonesian teachers in the learning process in SMP Negeri 2 Kinali. This type of research is a qualitative study with a descriptive method. Data collection is conducted through observation and recording of two Indonesian teachers who teach in class VII SMP Negeri 2 Kinali. The research Data is analyzed qualitatively based on the speech theory. The results of this study are as follows. First, the type of follow-up directive found was (1) to ask, (2) to have, (3) Beg, and (4) advise. The Act of Directive, which is dominant by Indonesian teachers, is that the teacher and the least used by the teachers is a follow-up directive. Secondly, the said strategy used to realize the follow-up directive in the learning process in class VII SMP Negeri 2 Kinali is (1) The strategy is frankly without further ado, (2) The strategy is frankly with positive civility, (3) The strategy is straightforward with a negative silence, and (4) a vague strategy. The strategy says frankly without the dominant unpleasantness teachers used in the learning process on the kind of follow-up said.
\end{abstract}

Keywords : Speech Acts directive, Recalled Strategy 


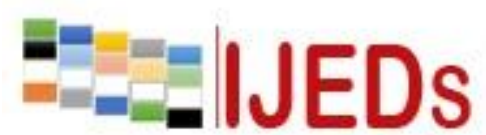

http://ijeds.ppj.unp.ac.id/index.php/IJEDS
International Journal of Educational Dynamics

Vol. 2 No. 1 (pp. 169-179) Desember 2019

p_ISSN 2655-4852

e_ISSN 2655-5093

\section{INTRODUCTION}

Speech acts used by students and teachers in the classroom interaction plays an important role during the process of learning takes place. One type of speech act is a directive speech act. In a directive speech, the speaker wants partners to do what he said he speak. Based on observations in SMP Negeri 2 Kinali, teachers tend to use directive speech acts other than speech acts in the learning process.

There are many studies in different parts of the world regarding speech acts. First, a study done in Turkey (Bayat, 2012). This study shows the findings of speech act carried out by participants from student teacher education program. Furthermore, research conducted in Jordan (Zayed, 2014). The results of this study contains findings on speech acts of students and teachers in speech. The interesting thing about this finding is the teachers and students who are the subject of research does not meet the criteria for a proper speech (there were no acknowledgments, greetings, apologies and compliments.

Subsequent research carried out carried out in Iran (Nourdad, 2016). This study discusses the speech act as pragmatic knowledge contained in the book of learning English to junior high students. A similar study carried out in Macedonia (Vaneva, 2018). This study shows the findings of a compliment speech act in English in the speech of students in Macedonia.

Teachers and students in communication acts as a speaker or hearer alternately. Teachers act as speakers when presenting learning materials, ask questions, provide explanations, and did not consent to show approval of the student speech. Students act as addressees when listening, studying, taking, or considering the instructional message delivered by teachers as the speakers. In contrast, students act as speakers when asked or ask a problem is not yet clear to the teachers, to answer the question raised by the teacher.

Based on observations in SMP Negeri 2 Kinali, teachers tend to use directive speech acts other than speech acts in the learning process in schools. It can be seen from the speech used by the Indonesian subject teachers in class VII. While studying aspects of listening to the news, the teacher assigns the students listen and record elements of $5 \mathrm{~W}+1 \mathrm{H}$ news was read. In the speech of teachers use strategies speak frankly without 


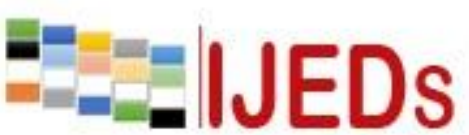

http://ijeds.ppj.unp.ac.id/index.php/IJEDS
International Journal of Educational Dynamics

Vol. 2 No. 1 (pp. 169-179) Desember 2019

p_ISSN 2655-4852

e_ISSN 2655-5093

further ado, it can be seen from the intended meaning teachers delivered directly to students without further ado. This speech needs to be discussed because in this speech seen how teachers in conveying the intent and desire to students.

The purpose of this study was to describe the speech act directives and strategies speak Indonesian teacher in the learning process in SMPN 2 Kinali. The measures displayed through speech act utterances usually called Yule (1996, p. 82). The opinion was corroborated by Austin (in Nadar 2009, p. 11), which explains that basically when someone says something he also did something. If someone promised to attend the invitation delivered to partners he said, he would take action in the form of meet or fulfill the promise that he said.

Furthermore, Wijana (1996, p. 36), distinguish the speech act to be: (a) the literal and direct speech acts; (B) speech acts are not literal and direct; (C) the literal speech acts and indirectly; (D) not literal speech acts and indirectly. One form of speech acts found in the learning process is a directive speech act. In this regard, Searle (in Abraham, 1993, pp. 27-32) directive speech act divides into six types, namely: (a) requesif (Demand), which includes requesting, pleading, commanding, pressing, invite, and encourage, (b) question (questions), which includes the question, inquiry, interrogated; (C) prohibition (prohibition), which includes prohibiting, restricting; (D) requirement (requirements) include wills, commanding, directing, demanding; (E) permesives (approval) which includes a approve, grant, permit, allow, forgive; $(\mathrm{F})$ Advisories (advice) that include advise, warn, propose and recommend.

According to Syahrul (2008, p. 127) tells strategies are grouped into two types, namely: (1) speak directly and (2) tells indirectly. Then speak directly called to speak frankly without further ado (bald on record). Furthermore speak with indirect classified into: (a) speak with the preamble of positive politeness, (b) speak with negative politeness, and (c) speak vaguely.

Bach and Harnis (quoted from Syahrul, 2008, p. 34) states that the directive speech acts are divided into five groups, namely: (a) a group request, plead, persuade, encourage, invite and press; (B) The group that includes the question asked, inquiry, and interrogated; (C) group of requirements that include commanding, commanding, demanding, dictating, directing, instructing, organizing, and require; (D) Group of the 


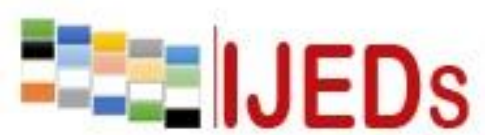

http://ijeds.ppj.unp.ac.id/index.php/IJEDS

\section{International Journal of Educational Dynamics}

Vol. 2 No. 1 (pp. 169-179) Desember 2019

p_ISSN 2655-4852

e_ISSN 2655-5093

ban, which includes prohibiting and limiting; (E) the extent permitted group that includes permit, allow, grant, release, allow, authorize, and grant; (F) The group's advice, who advise, warn, propose, counsel, advise and encourage.

Based on the grouping of the directive speech acts, it can be concluded that the directive speech acts are grouped into 5 categories. These categories are: (1) order, (2) ask, (3) suggest, and (4) request. In line with the theory put forward by Searle on speech acts directive grouping.

\section{METHOD}

This research is qualitative descriptive method. Qualitative research is research that aims to understand the phenomenon of what is experienced by subject the study such behavior, perception, motivation, act holistically, and by way of description in the form of words and language, in a specific context naturally and by utilizing a variety of methods natural (Moleong, 2010, p. 6). Furthermore, Sudaryanto (1993, p. 3) suggested that the descriptive method is used to describe a situation based on the facts or phenomena that are empirically- speakers live in speakers so that recorded in the form of language interpretation.

Qualitative research trying to see, observe and appreciate the issues to be investigated as a complex phenomenon. In addition, it should also be seen in a holistic or comprehensive (Syahrul, 2011, p. 17). This study aimed to describe the overall data, systematic and accurate. Data generated or recorded is data that are portrait as it is. This is consistent with the statement. Ratna (2006, p. 53) states that the descriptive analytic method is done by describing the facts which are then followed by analysis. Basically, the description is clear writing style so the reader can imagine what the teacher speech acts. Furthermore, according to Sudaryanto (1992, p. 62),

The subjects were Indonesian studies teachers who teach in class VII SMP Negeri 2 Kinali the 2015/2016 school year. The number of teachers who become the subject of research are two teachers who teach in class VII.

This research data is a directive speech acts Indonesian teacher in the learning process in class VII. Data collection techniques in this study were (1) observation, (2) recording, (3) recording. 


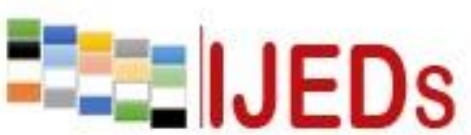

http://ijeds.ppj.unp.ac.id/index.php/IJEDS
International Journal of Educational Dynamics

Vol. 2 No. 1 (pp. 169-179) Desember 2019

p_ISSN 2655-4852

e_ISSN 2655-5093

Observation technique is a technique of data collection is done through observations. This technique is considered effective to record the phenomena that occur in the field. At the time of observation, used observation sheet that has been provided. It was observed covering all the events said, that directive speech act, speech acts are spoken strategy directive, directive speech act context of subject teachers when learning Indonesian.

At the time of the study, the researchers did not engage in a dialogue or a conversation. Researchers did not participate in the talks process people talk to each other (the speaker and hearer). Researchers who did not participate in the research record. This technique is called refer techniques. Meaning that the investigators did not act as a speaker in conflict with the conversation partner or as a conversation partner who needs to pay attention to what the speaker is saying. Researchers only as an observer to listen to what is being said by the teacher and the student in the learning process in the classroom.

Recording is carried out as the primary data collection techniques by recording, for the researchers present in the classroom when implemented learning process. Recording is done using camcorders Mobile. However, the study is not known what information the object of research, which they know is merely collecting data for the study. After recording, the recording is transcribed into written form.

To ensure the validity of the data that has been collected, carried out using the referential adequacy of conduct check. This is in accordance with the opinion Moleong (1998, p. 181) and Sugiono (2005, p. 128-129), to ensure the validity of data in qualitative research can be done by way of referential adequacy authentic form of documents (photographs, recordings, and video) and member checks in order to determine how far the data obtained in accordance with what is provided by the data providers. If the data is agreed upon by the data providers means that the data is valid. As authentic evidence of research already done member check, researchers attached a statement from the respective data providers.

Analyzing data in this study conducted by the steps as follows: (1) transcribing the research data in the form of speech into written form, (2) classifies speech directive based on the type of utterances, (3) classify speech acts directive is considered polite 


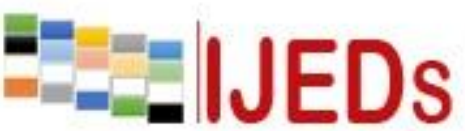

http://ijeds.ppj.unp.ac.id/index.php/IJEDS
International Journal of Educational Dynamics

Vol. 2 No. 1 (pp. 169-179) Desember 2019

p_ISSN 2655-4852

e_ISSN 2655-5093

and mannered by students, (4) identify and describe the types of utterances directive, (5) classifies the type of strategy says, (6) identify and explain the types of strategies recalled, (7) presents the results of data analysis, (8) summed up the results of the data analysis.

\section{RESULTS AND DISCUSSION}

\section{Types of Speech Acts Directives Teacher}

Based on the analysis of data, the type of speech acts directive Indonesian teachers can use in class VII SMP Negeri 2 Kinali in the learning process, which is sent, ask, advise, and begging. Type of directive speech acts found in the study can be seen in the table below.

Table 1. Number of Follow-Speech Directives Indonesian Teachers in Classroom Learning Process VII SMPN 2 Kinali

\begin{tabular}{|l|l|l|l|}
\hline $\begin{array}{l}\text { No } \\
\cdot\end{array}$ & $\begin{array}{l}\text { Follow- } \\
\text { Speech } \\
\text { Directives }\end{array}$ & J & Percent \\
\hline 1 & Asking & 88 & $54 \%$ \\
\hline 2 & tell & 56 & $36 \%$ \\
\hline 3 & Recommend & 8 & $6 \%$ \\
\hline 4 & appeal & 10 & $5 \%$ \\
\hline & amount & 162 & $100 \%$ \\
\hline
\end{tabular}

Based on the results of the study, analyzed the types of speech acts, the strategy says, and student responses used in the realization of directive speech by Indonesian teachers in the learning process in class VII SMP Negeri 2 Kinali. Based on data from this study, four forms of speech acts directive, namely (a) order, (b) asks, (c) suggest, and (d) request. Speak strategy used in the realization of speech acts directive Indonesian teacher in the learning process in class VII SMP Negeri 2 Kinali, four recalled strategy, namely (a) continuous light without further ado, (b) frankly with the preamble of positive politeness, (c) frank with pleasantries negative politeness and (d) vague.

\section{a. Tell}

Following the speech outlined the directive sent. More detailed description is as follows.

(1)Pn: Open book "Kartika" page 22 that the fast read 200 words / minute! (1) 


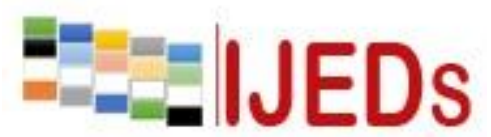

http://ijeds.ppj.unp.ac.id/index.php/IJEDS
International Journal of Educational Dynamics

Vol. 2 No. 1 (pp. 169-179) Desember 2019

p_ISSN 2655-4852

e_ISSN 2655-5093

Pt: (All students open the Pleiades open page 22) [KT 02 (25-8-16)]

Speech (1) is a directive speech kind of tell. In the speech (1) Pn Pt ordered "Kartika" to open books page 22 together with the strategy speak frankly without preamble when learning takes place. The situation occurred during the learning process when the teacher opened the learning activities. The teacher tells the students open book 22 page "Kartika" together. Speech (1) is a telling speech. Marker speech acts ordered in speech above is open.

Indonesian teacher in the learning process in class VII SMP Negeri 2 Kinali using speech acts sent to the speech topic sensitive situation and the atmosphere is not quiet. Context sensitive topic of speech situation is defined as a topic of conversation that might offend addressees or speech is personal, not related to the material. The atmosphere is not quiet a classroom situation when the learning process takes place in an atmosphere of uneasy or fuss.

\section{b. Asking}

Indonesian teacher in the learning process in class VII SMP Negeri 2 Kinali using speech acts speech asking situations sensitive topic and calm atmosphere. The context of the situation said sensitive topics interpreted as a topic of conversation that might offend the speaker or the speech of a personal nature are not related to the material. The atmosphere is quiet a classroom situation does not fuss when the learning process as the example below. Speech acts wondered insensitive and quiet atmosphere, can be seen in the example (2).

(2) Pn: It can be started?

Pt: Already, Mom.

\section{[KT01 (25-8-16)]}

Speech (2) is a type of directive speech asked. In the speech (2) Pn Pt asked about readiness to start learning $\mathrm{Pt}$. Although in the sentence there is no question words, but the purpose of the sentence dai is asking the readiness of students. Questions or question words conveyed implicitly. Marker speech act speech questioning in the above is already can. Speak strategy used is frankly preamble negative politeness because Pn recalled strategy used is frankly preamble negative politeness because Pn asked without use of address. Therefore, speech (1) is a speech asking. Indonesian teacher in the 


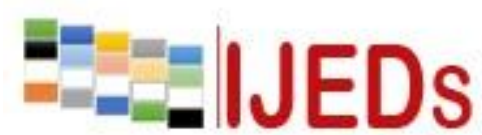

http://ijeds.ppj.unp.ac.id/index.php/IJEDS
International Journal of Educational Dynamics

Vol. 2 No. 1 (pp. 169-179) Desember 2019

p_ISSN 2655-4852

e_ISSN 2655-5093

learning process in class VII SMP Negeri 2 Kinali using speech acts speech asking situation is not sensitive topic and calm atmosphere.

\section{c. Recommend}

Indonesian teacher in the learning process in class VII SMP Negeri 2 Kinali using speech acts speech advise on the situation sensitive topic and calm atmosphere. The context of the situation said sensitive topics interpreted as a topic of conversation that might offend addressees or private utterance was not associated with the material. The atmosphere is quiet a classroom situation does not fuss when the learning process as an example (3).

(3) Pn: Try repeating again Rica Kiyani.

Pt (Answering shame)

\section{[KT 46 (27-8-16)]}

Speech (3) is a directive speech acts suggests. In the speech (3) Pn suggest to Pt to try to repeat the answer he had to say because they have not heard clearly biased by Pn. Strategy speak directly with the preamble of positive politeness with a speech that uses the speech greeting. In words suggest a direct teachers to students to not forget. Speech (5) is a suggested speech acts. Marker speech acts suggested in the narrative above is not to forget.

\section{d. appeal}

Indonesian teacher in the learning process in class VII SMP Negeri 2 Kinali using speech acts speech begging situation sensitive topic and calm atmosphere. The context of the situation said sensitive topics interpreted as a topic of conversation that might offend addressees or private utterance was not associated with the material. Speech acts pleaded in insensitive and quiet atmosphere, can be seen in the example (4).

(4) Pn: Please you read from the beginning to the end of Damarwulan.

Pt: (Students answer)

\section{[KT 38 (25-8-16)]}

The above narrative is a kind of pleading a directive speech act. In the speech Pn Pt begged to read literature on Damarwulan from beginning to end. Speak strategy is frankly no- nonsense with a speech that used the word greetings. In the speech teacher 


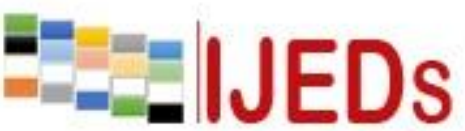

http://ijeds.ppj.unp.ac.id/index.php/IJEDS
International Journal of Educational Dynamics

Vol. 2 No. 1 (pp. 169-179) Desember 2019

p_ISSN 2655-4852

e_ISSN 2655-5093

directly appealed to the students to understand what has been discussed previously. Teachers requested that the students understand the material that has been studied.

\section{Strategies used speak Indonesian teachers in the process of learning in class VII}

\section{SMP Negeri 2 Kinali.}

Strategies used by teachers speak Indonesian in the process of learning in class VII SMP Negeri 2 Kinali found recalled three-pronged strategy, which is frankly a nononsense, frankly positive politeness with strings attached, frankly with strings attached negative politeness, and murmur sketchy. The strategy found in the utterances spoken Indonesian teacher in the learning process in class VII SMP Negeri 2 Kinali can be seen in the following table.

Table 2 Strategy speak Found in Speech Acts Directives Indonesian Teachers in the Classroom Learning Process VII SMP Negeri 2 Kinali

\begin{tabular}{|c|c|c|c|}
\hline No & $\begin{array}{lr}\text { Strategy } & \text { speak } \\
\text { According } & \text { to } \\
\text { Brown } & \text { and } \\
\text { Levinson } & \end{array}$ & $\mathbf{J}$ & Percent \\
\hline 1 & $\begin{array}{l}\text { Frankly Without } \\
\text { pleasantries }\end{array}$ & 76 & $47 \%$ \\
\hline 2 & $\begin{array}{ll}\text { Frankly } & \text { With } \\
\text { Smalltalk } & \\
\text { Politeness } & \\
\text { Negatives } & \end{array}$ & 49 & $30 \%$ \\
\hline 3 & $\begin{array}{ll}\text { Frankly } & \text { With } \\
\text { Smalltalk } & \\
\text { Politeness } & \\
\text { Positive } & \end{array}$ & 19 & $12 \%$ \\
\hline 4 & Vaguely & 18 & $11 \%$ \\
\hline \multicolumn{2}{|c|}{ amount } & 162 & $100 \%$ \\
\hline
\end{tabular}

Strategies used speak Indonesian teacher in the learning process in class VII SMP Negeri 2 Kinali studied the theory proposed by Brown and Levinson (1987). Based on data from this study, it was found forms recalled strategy directive ordering, ask, advise, and begging. Strategy tells used speakers are (1) plainly without further ado, (2) frank with the niceties of politeness positive, (3) frankly with small politeness politeness, and (4) vague. Forms tells strategies used in the realization of speech directive Indonesian teacher in the learning process in class VII SMP Negeri 2 Kinali will be described one by one as follows. 


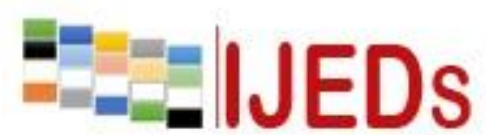

http://ijeds.ppj.unp.ac.id/index.php/IJEDS
International Journal of Educational Dynamics

Vol. 2 No. 1 (pp. 169-179) Desember 2019

p_ISSN 2655-4852

e_ISSN 2655-5093

\section{CONCLUSION}

Based on data analysis conclusions about the type of speech act directive, recalled strategies used by teachers and students in response to the directive speech acts used in the learning process as follows. First, the type of directive speech acts were found: (1) ask, (2) order, (3) request, and (4) suggest. The directive speech acts predominantly found is asked directive speech acts. Second, the strategy tells used to realize the speech acts directive in the learning process in class VII SMP Negeri 2 Kinali is (1) strategy of continuous light without further ado, (2) the strategy frankly with the niceties of politeness positive, (3) strategy frankly with negative politeness preamble, and (4) the strategy vague. Speak dominant strategy is a strategy frankly found without further ado. students and appropriately used in the learning process. Second, the strategy speech spoken in realizing the directive by the teacher in the learning process in Junior High School 2 Kinali there are four kinds: (1) strategy of continuous light without further ado, (2) strategy continues bright with strings attached positive politeness, (3) small talk frankly with negative politeness, and (4) strategies cryptic. Strategy vaguely recalled frankly without further ado dominant use of teachers in the learning process in the order of speech acts.

\section{REFERENCES}

Bayat, Nihat. (2012). A Study on the Use of Speech Acts. Proceria Social and Behavioral Science, (Online), Vol. 3, No. 1, (www.sciencedirect.com), Accessed on February 17, 2019).

Gredler, Margaret E. Bell. (1991). Learning and learn Jakarta: Rajawali Pers.

Hasan, Masrizal. (2011). Speech Acts of Indonesian Teachers in Learning at SMP N 37 Padang A Study of Pragmatics. Thesis. Padang State University: Studi Program Language and Literature Indonesia, Padang State University Graduate Program.

Ibrahim, AS (1993). Study of Speech Acts. Surabaya: National Business.

Leech, Geoffrey. (1993). Principles of Pragmatics. Jakarta: Indonesian University.

Nadar, FX (2009). Pragmatics and Pragmatic Research. Yogyakarta: Graha Science.

Mulyana, Deddy. (2005). Human Cominication. Bandung: Teen Rosda paper.

Moleong, Lexi J. (2007). Qualitative Research Methodology. Revised Edition. Bandung: Youth Rosdakarya.

Nurmala. (2012). Follow-Speech Teacher Directives in Learning Process in MTS Emigrants Nanas Kuala Kampar. Thesis. Padang State University: Study 
http://ijeds.ppj.unp.ac.id/index.php/IJEDS

Program of Indonesian Language and Literature, Graduate Program, State University of Padang.

Nourdad, Nava. (2016).Evaluation of Speech Acts in the Newly Developed Iranian EFL English Textbooks, Modern Journal of Language Teaching Methods, (Online), Vol. 4, No. 2, (www.mjltm.org), Accessed on February 17, 2019).

Rahardi, R. Konjana. (2008). Politeness Pragmatics Indonesian Imperative. Jakarta: Erland.

Rachmat, Jalaludin. (1999). Psychology of Communication. Bandung: Teen Rosda paper.

Ratna, Nyoman Kutha. 2006. Theory, Methods and Techniques Research Letters. Yogyakarta: Student Library.

Sudaryanto. (1992). "Linguistic Method First part to the Direction Understanding Linguistic Method". Yokyakarta: Gajah Mada University.

Sugiono. (2010). Quantitative Research Methods, Qualitative and R \& D Bandung: Alfabeta.

Ramadan, Syahrul (2008). Pragmatic Politeness Phenomena Drill Speak Indonesian Language Teachers and Students. Padang: UNP Press.

Thontowi, Ahmad. (1991). Educational Psychology. Bandung. Space.

Wijana, I DewaPutu. (1996). Fundamentals of Pragmatics. Yogyakarta: Andi.

Yuyuk, Sari Satria. (2011). Follow-Speech Teacher Directives in Learning Process in MTSN Langgam Kinali West Pasaman. Thesis. Padang State University: Study Program of Indonesian Language and Literature, Graduate Program, State University of Padang.

Yule, George. (2006). Pragmatics. Translation Beautiful Dawn Wahyuni. Yogyakarta: Student Library.

Vaneva, Marjana. (2018).Pragmatics of English Speech Acts: Compliments Used by Macedonian Learners, Interntional Journal of English Linguistics, (Online), Vol. 8, No. 5, (www.ijjel.cesenet.org), Accessed on February 17, 2019).

Zayed, Mohammad Niven. (2014). Jordanian EFL Teachers and Student's Practice of speech Acts in the Classroom. Interntional Journal on Studies in English Language and Literature, (Online), Vol. 5, No. 2, (www.arcjournal.org), Accessed on February 17, 2019). 